\title{
Aristoteles se siening van dramatiese spanning in die tragedie en die invloed daarvan op moderne dramateorie
}

\begin{abstract}
Aristotle's remarks about dramatic suspense in the Poetics are so diffuse and divergent in nature that it seems highly unlikely that he meant them to be regarded as a systematic theory on this subject. Yet his views in this regard - although set down in writing some 2400 years ago - are still in many respects the basis of modern drama theory. The emphasis which he places on the linear plot and on causal connection is an early recognition of two very important requisites for unity in a drama. The phases in the course of action which he pointed out and on which scholars like Scaliger, Freytag and Verhagen have built their theories, are still accepted in broad outline today. The desirability of concentrated action and of the identification of the spectator with the dramatis personae are factors which are still valid. And finally, his discussion of the effect which tragedy has on the spectators is the point of departure of modem reader-oriented theories.
\end{abstract}

Dramatiese spanning is deur die jare heen al met behulp van talle verskillende beelde voorgestel. So het Verhagen (1963:55) byvoorbeeld die dramatiese stuwingslyn, soos hy dit noem, vergelyk met 'n koorsgrafiek wat die innerlike bewoënheid en die wisseling van die emosies van die dramatiese figure andui. Levitt (1971:13) weer, het dramatiese spanning vergelyk met 'n kardiografiese lesing van die ritme van 'n drama. Hierdie en ander beelde beklemtoon almal die belangrikheid van dramatiese spanning. Dit is, trouens, nie net belangrik nie, maar onmisbaar, want elke drama, antiek en modern, het 'n sekere mate van spanning nodig ten einde die kyker/leser ${ }^{1}$ se belangstelling te behou. Dit is dus vreemd dat daar so min navorsing oor hierdie onderwerp gedoen is. ${ }^{2}$ Ook is daar nog geen grondige ondersoek gedoen na Aristoteles se siening van dramatiese spanning nie, en dit terwyl die meeste van die moderne insigte daaromtrent reeds in kiemvorm in die Poëtika te bespeur is. Dit word weliswaar nie as 'n sistematiese teorie aangebied nie, maar moet uit

1 Bcide Taplin (1978:162) en Kenyon (1951:25) glo dat daar in dic vicrde ceu v.C. recds 'n leserspublick was. Hierna verteenwoordig 'n verwysing na 'toeskoucrs' in hierdie studie dus 'tocskouers' en 'lesers'.

2 Dit is ook dic siening van Comisky en Bryant (1982:50) en Ohlander (1985:309). In dic afgelope dekades het slegs Pütz. (1970) en Pfister (1988) die verskynsel as sodanig grondig behandel. Meer gespesialiseerde besprekings van dramatiese spanning in spesifieke dramas is die van Stuart (1918), Pratt (1939), Goodine (1977) en Ohlander (1985). 
verskillende kontekste bymekaargebring word, soos die geval is met verskeie van Aristoteles se sienings oor belangrike sake in die Poëtika. Dit is dus die doel van hierdie artikel om die veelsoortige opmerkings omtrent dramatiese spanning wat in die loop van die Poëtika voorkom, byeen te bring en aan te toon dat moderne teorie $\ddot{3}$ in velerlei opsigte slegs ' $n$ herhaling en/of ' $n$ aanpassing en/of ' $n$ verdere ontwikkeling is van opmerkings wat Aristoteles sowat 2400 jaar gelede reeds in sy Poëtika gemaak het.

\section{Verskillende soorte dramatiese spanning}

\subsection{Spanning in 'n Griekse tragedie met 'n plot wat bekend is}

Aristoteles se teorieë in die Poëtika is gebaseer op die klassieke Griekse tragedie van die vyfde en vierde eeue v.C. Die vraag kom dadelik by 'n mens op of daar in die geheel van dramatiese spanning in hierdie tragedies sprake kan wees, aangesien dit tog algemeen aanvaar word dat die mites wat as basis van die plots gedien het, aan almal bekend was. Hierdie siening is gebaseer op 'n fragment van Antiphanes, 'n Middel-komedieskrywer van die vierde eeu v.C., waarin hy die probleme van komedieskrywers bespreck wat op hul eie kreatiwiteit moet staatmaak, in teenstelling met die tragedieskrywers wat daarop kan reken dat die toeskouers die plot geken het (fragment 191, Kock, 1884:90-91). By nadere ondersoek blyk dit dat hierdie bewering nie noodwendig 'n universele waarheid is nie. Benewens die feit dat 'n komediefragment nie as bewysstuk in ' $n$ argument gebruik kan word nie, moet 'n mens in gedagte hou dat daar in die vyfde en vierde eeue v.C. 'n magdom mites in omloop moes gewees het. Die groot trias, Aischulos, Sophokles en Euripides alleen het sowat 230 tragedies geskryf; daarbenewens ken ons die name van 141 Griekse tragedieskrywers en die titels van 387 dramas. Baie van hierdie tragedies was wel op dieselfde mites gebaseer (vgl. Po. 14.54a9-13), maar die dramaturge het groot vryheid gehad in die hantering van die mites (Po. 14.53b22-26). Pratt (1939:10) is dus waarskynlik korrek in sy konklusie dat "the audience's familiarity with the stories of tragedy has been greatly exaggerated. Even the minority generally acquainted with the traditions might of ten be confused by the bulk, variety, and intricacy of the myths as well as by the elaborations and changes wrought by the dramatists". 3

'n Mens kan dus aanvaar dat die merendeel van die toeskouers nie bekend sou gewees het met die plots van die dramas nie. Maar daar was ook diegene - waarskynlik 'n klein groepie hoogs gekultiveerde mense - wat wel in breë trekke sou kon vermoed waarop die handelingsverloop afstuur. Die vraag moet dus steeds beantwoord word of hulle enige spanning sou ervaar het by die aanskouing van 'n drama, en indien wel, waarin dit sou lê. Thompson (1946:146) 4 bied die volgende antwoord:

Suspense does not, like surprise, depend on the spectator's ignorance of what is to follow. It is strongest when the spectator knows or at least suspects the outcome, as when we sec a swimmer helplessly drawn to the brink of a waterfall.

3 Dit is ook die mening van Taplin (1978:162-164), Conradic (1979:15) en Ohlander (1985:37-38) wat almal die siening verwerp dat die toeskoucrs bloot by die aanhoor van die titel van 'n drama sou weet wat gaan gebeur.

4 Vgl. ook Conradie (1979:15) vir byna dieselfde siening: "As die toeskouer weet dat dic held onbewus op 'n ramp afstuur, is die spanning by hom net so groot as wannecr hy onscker is oor wat gaan gebeur." 
Hierdie beeld is ' $n$ duidelike illustrasie van die feit dat dit die belewenis van die enkelmoment is wat tel - dit is amper of ons by die aanskouing van 'n drama in 'n toestand van onwetendheid herstel word, en dit dus opnuut as spanningsvol sal ervaar.5 Hierdie eienaardige verskynsel kan gedeeltelik verduidelik word deur die bewese feit dat die belewenis van 'n drama binne groepsverband 'n meer intense ervaring daarvan meebring. 6

Ook die toekomsgerigtheid van drama sal 'n rol speel: ${ }^{7}$ die voortstuwende krag sleur die toeskouer mee en wek verwagtinge selfs teen die wete van waarop die gebeure afstuur. Daar is egter ook ander meer voor die hand liggende redes waarom toeskouers 'n drama waarvan hulle die afloop ken, sal geniet: alhoewel hulle mag weet wat gaan gebeur, weet hulle nog nie hoe dit gaan gebeur nie en ook nie hoe die dramatiese figure daarop gaan reageer nie.

\subsection{Voorkennis al dan nie omtrent die plot vir Aristoteles irrelevant}

Voorkennis omtrent die afloop van gebeure was, wat Aristoteles betref, van geen belang nie, aangesien bekende en onbekende temas volgens hom ewe veel genot verskaf. Feitlik deurgaans aanvaar hy in die Poëtika sonder kritiek die praktyk van digters om die tradisionele mites as onderwerp van hul tragedies te neem. In hoofstuk 9 maak hy egter die verrassende stelling dat dit absurd vir digters is om vas te klou aan die oorgelewerde verhale, aangesien ook hierdie bekende temas slegs aan enkele mense bekend is. Dramas waarin sowel die plots as die karakters nuut uitgedink is, verskaf ewe veel genot ( $P O$. 9.51b19-26). Die geïmpliseerde aanbeveling is dus dat die tragediedigters gefingeerde verhale vir hul plots moet neem eerder as welbekende historiese materiaal. Dit was egter kennelik nie in ooreenstemming met die gevoelens van die dramaturge en die gehoor van sy tyd nie. 8 Vir hulle was die reeds bestaande historiese karakters met die mites wat om hulle verweef was, verkiesliker omdat 'n sodanige verloop van gebeure reeds in die verlede moontlik blyk te gewees het en dus volgens hulle meer oortuigend sou wees (9.51b15-19). Aristoteles sien egter die kern van die saak raak, te wete dat dit in teenstelling met die geskiedskrywing wat hom met besonderhede besig hou, in die digkuns om die universele gaan, met ander woorde om dié soort dinge wat 'n sekere soort persoon onder sekere omstandighede waarskynlik of onvermydelik sal sê of doen (9.51a36-b11). Vanuit hierdie perspektief waar die riglyn vir die keuse van die stof die beginsel van die waarskynlike of

5 Vgl. ook Pütz (1970:14): "Dic Wiederholung hebı die Spannung also nicht auf."

6 So gestel deur onder andere Hamilton (1939:23) en Hall (1981:734). Volgens Nicoll (1962:22) bring die groepsidentiteit mee dat die toeskouers emosioneel toegankliker is $\mathrm{en} \mathrm{meer} \mathrm{betrokke}$ raak by dic gebeure in dic drama. Ook Aristoteles erken dat dic visuelc komponent dic mecsleurendste van die ses kwalitatiewe komponente van tragedic is (6.50bl6-18; vgl. ook 14.53b1-3).

7 Vgl. ook Mouton (1989:111): "Dit is veral hicrdic gedurige afwagting op wat nog moct volg wat dic toeskouer geinteresseerd hou in dic fiksionele werreld voor hom en dus ook spanning by hom skep ten opsigte van die afloop van hierdic gebeure." Vgl. ook Langer (1953:311) wat die drama as "a form in suspense" beskryf.

8 Dat Aristoteles hier op dic verdediging is, blyk duidelik uit sy formulering in 9.51b.21-26: hy vind dit naamlik nodig om twee maal binne ses reëls te sê dat vrye skeppings desnieteenstaande genot verskaf, en dat selfs die bekende temas aan min bekend is, maar nietemin aan almal genot verskaf. 
noodwendige is, is dit duidelik dat dit irrelevant is of die stof reeds bekende mites of vrye skeppings is.

\subsection{Spanning van onsekerheid en spanning van afwagting}

Dit blyk dus dat daar twee oënskynlik teenstrydige soorte dramatiese spanning is, te wete dié wat voortspruit uit onkunde omtrent die afloop van die gebeure, en dié wat teweeggebring word deur kennis omtrent die uiteinde van die drama. Verskeie dramateoretici (vgl. onder andere Pratt, 1939:1, en in minder detail ook Pütz, 1970:11 en Dawson, 1970:32) het dan ook 'n onderskeid gemaak tussen

- die spanning van onsekerheid oor die onbekende toekoms (die wat-gaan-gebeur spanning), en

* die spanning van afwagting vir 'n reeds bekende toekoms (die hoe-gaan-dit-gebeur spanning).

Daar is egter etlike geleerdes (vgl. onder andere Pfister, 1988:99) wat daarop gewys het dat dié twee pole in die praktyk nie so skerp te onderskei is nie omdat totale onkunde 'n totale oop toekoms meebring wat hipoteses op grond waarvan verwagtinge gevorm kan word, onmoontlik maak; daarenteen sal totale geïnformeerdheid alle onkunde ophef en daarmee alle spanning uitskakel. 'n Mens sou dus kon sê dat dramatiese spanning voortspruit uit gedeeltelike kennis, wat 'n toestand tussen volkome onkunde en volkome kennis is (vgl. Pütz, 1970:11 en ook Dawson, 1970:32).

\section{4 'n Definisie van dramatiese spanning}

Dit is duidelik dat dramatiese spanning baie fasette het. Dit is gevolglik baie moeilik om 'n definisie te formuleer wat bondig en tog presies genoeg is. Waarskynlik is die mees omvattende dog bondige definisie dié wat deur Van Gorp (1986:381) in sy Lexicon van literaire termen gegee word:

\footnotetext{
Dit begrip kan worden gemterpretcerd als de samenwerking van factoren in ecn verhaal, toneclstuk, film enz. waardoor de betrokkenheid van de lezer (of kijker) gestimuleerd word en zijn aandacht gericht op de ontknoping der gebeurtenissen. Verschillende technicken om dat te bereiken berusten op cen manipulatic van de geboden informatic.
}

\section{Die plotstruktuur as bepalende faktor vir die verwekking van dramatiese spanning}

\subsection{Die liniêre plot vs. die kontekstuele plot}

In die bostaande onderskeiding tussen dramatiese spanning wat voortspruit uit onsekerheid omtrent en uit afwagting vir die afloop van gebeure, is daar uitgegaan van die veronderstelling dat ons te doen het met ' $n$ liniêre opvolging van gebeure in die struktuur van die dramateks, dit is 'n plot waarin daar 'n ordelike progressie van gebeure van begin tot einde is wat deur 'n kousale samehang gebind is. Hierteenoor is daar die kontekstuele plot ${ }^{9}$ wat

9 Drama- en teaterscmiotici het dic onderskeid wat dic Russiese Formaliste tussen fahula (dic 
byvoorbeeld in etlike van Aristophanes se komedies aangetref word. In hierdie soort plot is daar nie 'n progressie van kousaal-verknoopte gebeure nie, maar word 'n situasie ondersoek en word al die fasette van menslike optrede in daardie bepaalde konteks uitgebeeld. "Vertical depth rather than horizontal movement" is hier van belang (Goodine, 1977:17). Gebeure vind arbitrêr plaas en episodes word eerder ter wille van die komiese effek ingevoeg as om die handeling te bevorder.

In die Poëtika is daar kennelik nie sprake van 'n kontekstuele tipe plot nie. Aristoteles sê naamlik herhaaldelik dat die handelingsverloop die belangrikste komponent van die tragedie is (Po. 6.49b36, 6.50b3, 6.50a22-23 en 6.50a38). Die gebeure is ordelik gerangskik (7.50b35-36) in soverre die tragedie 'n geheel is met 'n begin, 'n middel en 'n einde (7.50b25-27) en nie by 'n willekeurige punt begin of eindig nie (7.50b33-35).

Dit is dus duidelik dat daar slegs in 'n liniêre plot waar daar 'n logiese ontwikkeling in die opeenvolging van gebeure is, werklik sprake kan wees van die geleidelike opbou van 'n dramatiese spanningslyn. In die kontekstuele plot sou 'n mens miskien korttermynspanning binne elke episode kon aantref, maar as gevolg van die arbitrêre wyse waarop gebeure plaasvind, is dit nie vir die toeskouer moontlik om langtermynverwagtinge met betrekking tot die toekoms te vorm nie.

\subsection{Kousale samehang}

In 'n liniêre plot is dit noodsaaklik dat die gebeure in 'n kousale samehang moet wees. In moderne dramateorie bespreek P.M. Levitt byvoorbeeld "the law of good continuation" en "the law of closure", beginsels wat vanuit 'n sielkundige oogpunt onontbeerlik is omdat dit die verskillende tonele van 'n drama in 'n bepaalde verhouding met mekaar plaas. ${ }^{10}$

Die vereiste dat gebeure in 'n kousale samehang moet wees sodat dit waarskynlik of noodwendig is dat hulle mekaar opvolg, word baie sterk deur Aristoteles in die Poëtika beklemtoon: in feitlik al die aspekte van die tragedieplot wat hy bespreek, kom dit na vore. As hy byvoorbeeld die gepaste perk vir die lengte van 'n tragedie bespreek, is dit dié lengte waarbinne 'n ommeswaai van geluk na ongeluk of andersom kan plaasvind in 'n reeks gebeure waar dit waarskynlik of noodwendig is dat hulle mekaar opvolg (7.51al2-15). En wanneer Aristoteles die strukturering van vrees- en medelywekkende gebeure bespreek, blyk dit ook daar dat dit die mees effektiewe sal wees as dit teen die verwagting in, maar

onverwerkte stof, dic hele storic wat op logies-kronologiese wyse deur dic leser/tocskouer vir homself geabstraheer word uit die sjuzet) en sjuzet (dic plot, oftewel dic kunstenaar se verwerking en rangskikking van die onverwerkte stof tot 'n kunswerk) gemaak het, ook op die drama toegepas. Elam (1980:119) wys egter daarop dat die drama, omdat dit mimeties eerder as diègeties is, sigself nie lecn tot "a distinction between narrative order and the structure of events" nic, maar dat dic sjuzet/fabula-onderskeid tog op die drama toegepas kan word omdat nie alle gebeure weergegec word nie (kyk 4.2 op p. 34), die plot van een lyn van aksie oorgaan tot 'n ander, en daar gapings in dic temporele struktuur is.

10 Vgl. Levitt (1971:52) se verduideliking: "... with the law of good continuation the carlier scenes in a play constitute an incipient order, an inchoate pattern of experience, which the succeeding scenes must continue in a 'good' way or be received as 'bad' or 'irrelevant'. And in accordance with the law of closure, a play is satisfactorily concluded when the succeeding seenes have completed the pattern in a 'good' way". 
tog ten gevolge van mekaar plaasvind (9.52a l-4). Hierdie beginsel word ook toegepas op peripetie (11.52a22-24), en selfs in die uitbeelding van die dramatiese figure moet daar steeds na die noodwendige of waarskynlike gesoek word (15.54a33-36). Kortom, die plot moet niks onwaarskynliks bevat nie $(24.60 \mathrm{a} 28-29$; vgl. verder $8.51 \mathrm{a} 32-34,9.51 \mathrm{~b} 30-31$ en 9.51b33-35).

Dit is dus duidelik dat die beginsel van waarskynlikheid of noodwendigheid 'n baie belangrike rol in Aristoteles se dramateorie in die Poëtika speel. Dit is nie verbasend nie, aangesien dit een van die belangrikste faktore is wat eenheid in 'n plot bewerkstellig. Vanuit die oogpunt van dramatiese spanning wat, soos reeds geblyk het, slegs in 'n liniêre plot sy volle potensiaal kan bereik, kan die belangrikheid van kousale samehang dus nie sterk genoeg beklemtoon word nie.

\section{Verskillende beskouings van die plot, gegrond op die verloop van die dramatiese spanningslyn}

\subsection{Aristoteles}

Die op- en afgaan van die dramatiese spanningslyn in 'n drama bring mee dat die handelingsverloop verskillende fases vertoon. Alhoewel Aristoteles oënskynlik nie die begrip dramatiese spanning geken het nie, het hy kennelik hierdie fases aangevoel, want hy onderskei tussen twee ontwikkelingstadia in 'n drama, te wete die verknoping oftewel die 'verdigting' van die spanning (desis) en die ontknoping of tewel die 'verligting' van die spanning (lusis) (18.55b26-29). Die belangrike rol van die draaipunt, oftewel die ommekeer van die plot in hierdie spanningslyn kom ook telkens na vore. Aristoteles waarsku egter dat die ommekeer nie die kontinuïteit van die handelingsverloop moet verbreek nie, en beveel dus aan dat die gebeure steeds ten gevolge van mekaar (9.52a4) plaasvind. As die ommekeer 'n té verrassende wending meebring, sal die toeskouer nie voorbereid wees nie en sal die verloop van sake hom koud laat. Vele eeue later sou navorsing in moderne dramakonstruksie en doeltreffende kommunikasie Aristoteles se siening bevestig: veel minder spanning word verwek wanneer die toeskouer nie voorbereid is op die verloop van gebeure nie en nie tyd het om werklik betrokke te raak nie. ${ }^{11}$

\subsection{Die beginsel van die indeling van die plot in episodes/bedrywe en koorliedere/pouses}

Ná Aristoteles se identifisering van die ontwikkelingsfases in die plot, was daar deur die eeue heen nog talle ander indelingsprinsipes wat almal basies herlei kan word na pogings om 'n beter insig in die voortgang van die handeling te kry. Baie van hierdie pogings berus op 'n besondere siening van dramatiese spanning. Die mees voor die hand liggende

$11 \quad \mathrm{Vgl}$. in hierdic verband Griffiths (1988:29): "The superiority of suspense to surprise is worth emphasizing. The playwright has a better ally in the complicity of the audience than its ignorance ... If we know a bomb is planted under the confcrence table, we watch the entire proceedings in a high state of tension, and still get a shock when it gocs off. If we do not know it is there, a minute's worth of shock is obtained when it explodes, compared with many minutes worth of suspense in the other instance." Ook Conradie (1979:14) en Comisky en Bryant (1982:50) huldig dieselfde sicning. 
indeling is dié deur die dramaturg self wat koorliedere of pouses tussen die episodes of bedrywe invoeg. 12 Hierdie indeling wat teruggaan na die oorsprong van Griekse tragedie as koorliedere met stukkies dialoog tussenin, het die meriete dat dit baie praktykgerig is in soverre dit die menslike faktor van uitputting aan die kant van sowel die akteurs as die toeskouers in ag neem. Dit kan in 'n groot mate voorkom word deur 'n kort verposing in die spanningslyn, selfs in die vorm van 'n koorlied wat op liriese wyse kommentaar bied op universele waarhede. Alhoewel dit na 'n baie oppervlakkige indeling lyk en nie met die geleidelike opbou van spanning deur die ontplooiing van die intrige rekening hou nie, vereis dit aansienlike vaardigheid aan die kant van die dramaturg om die aandag van die toeskouers tydens die pouse te behou deur die spanning nie heeltemal te laat verslap nie, maar slegs tydelik op te skort. ${ }^{13}$

\subsection{Gustav Freytag se piramide-vormige siening van die fases van 'n drama}

'n Verdere ontwikkeling en uitbreiding van Aristoteles se identifisering van die verknoping en ontknoping word aangetref in die laat-Klassieke model van Julius Scaliger, wat onderskei het tussen die protasis, epitasis, katastasis en katastrophe. 'n Verfynde weergawe van hierdie skema is in die negentiende eeu voorgestel deur Gustav Freytag (1965 (1922):102-122), wat hierdie skema as 'n normatiewe ideaal voorgehou het. Hy het vyf fases in die handelingsverloop onderskei, te wete die inleiding, stygende beweging, hoogtepunt, ommekeer en katastrofe, wat hy in 'n piramide-vormige struktuur rangskik met die klimaks as die hoogtepunt in die middel. Daar is uiteenlopende sienings oor hierdie indeling; die ernstigste punt van kritiek is egter dat dit slegs op 'n heel selektiewe aantal dramas toegepas kan word (volgens Pfister, 1988:239-240). Hierdie model kan egter vandag nog op dramas met 'n geslote dramastruktuur ${ }^{14}$ toegepas word in die vorm eksposisie, verwikkeling, klimaks, katastrofe/afwikkeling en slottoneel (uiteengesit en bespreek deur Conradie, 1979:8-11).

\subsection{Verhagen se indeling, gebaseer op die verloop van die dramatiese stuwingslyn}

'n Minder rigiede indeling van die plot (waarin dieselfde fases egter nog onderskei word) is dié van Verhagen (1963:51-54), wat vyf verskillende tipes plots onderskei op grond van die verloop van die dramatiese stuwingslyn. Daar is dié plots waarvan die spanningslyn op 'n laagtepunt begin en styg tot 'n hoogtepunt, en omgekeerd. Dan is daar dié wat op 'n laagtepunt begin, styg na 'n hoogtepunt en terugval na 'n laagtepunt, en omgekeerd. Ten slotte vind 'n mens plots met 'n kruising van 'n stygende en dalende spanningslyn.

12 Die voorskrif dat daar 5 episodes in elke drama moet wees, kom nêrens in die Poëtika voor nic, maar is ccrs sowat 300 ) jaar later deur Horatius in sy Ars Poetica (rcëls 189-190) geformulecr.

13 'n Tydelike opskorting van dic spanning kan egter baic cffekticf wees. Verhagen (1963:94) wys byvoorbecld daarop hoc Shakespeare in Macbeth die moord op Duncan skei van die ontdekking daarvan deur dic somber grappe van dic dronk porticr. Deur spanning na dic agtergrond te skuif word dit dikwels juis intenser gemaak.

14 Dic geslote dramavorm word deur Mouton (1989:162, mct verwysing na Pfister) beskryf as 'n klassisistiese vorm waar alle konfliktc 'n afloop het, geen onafhanklike toncle agterbly nic, en waar daar 'n duidelike slotaanduiding is. 
Alhoewel Verhagen en Freytag se sienings van die plot nuttige algemene aanduidings van die verskillende fases is, moet hul waarde nie oorskat word nie. Dit is nie altyd moontlik om die fases van mekaar te onderskei nie, aangesien hulle dikwels oorvleuel, nie ewe lank is nie en nie noodwendig met die vyf tradisionele bedrywe saamval nie.

\section{Faktore wat gekonsentreerde handeling in 'n drama bepaal}

\subsection{Lengte}

Aristoteles se opmerking dat tragedie daarna streef om sover moontlik "binne een omwenteling van die son te bly of om maar weinig hiervan af te wyk, terwyl epos onbegrensd is ten opsigte van tyd" (5.49b12-14), het deur die eeue heen tot groot meningsverskille aanleiding gegee. Die waarskynlikste interpretasie is dié van D.W. Lucas (1968:94) wat glo dat Aristoteles se opmerking na voorgestelde tyd verwys wat in teenstelling met voorstellings$t y d,{ }^{15}$ na die tydsverloop in die plot van die drama verwys. Alhoewel die tragedies van die laat-sesde en vroeg vyfde-eeue v.C. meer omvangryke temas gehad het (5.49b13-16) wat oor jare gestrek het (Aischulos se Tebaanse trilogie strek oor drie geslagte heen), vind 'n mens dat byna al Sophokles en Euripides se tragedies binne een omwenteling van die son afspeel. Aangesien Sophokles se Oidipus Turannos so hoog aangeslaan is deur Aristoteles (vgl. onder andere Po. 11.52a24-26, 14.53b29-31 en 15.54b6-8), is dit waarskynlik dat die bostaande opmerking na Sophokles en Euripides se dramas verwys waarin die gebeure kort op mekaar volg, met die gevolg dat die handeling meer gekonsentreerd is as wanneer die gebeure oor 'n lang tyd uitgesprei is.

\subsection{Selektiewe keuse van stof}

Aristoteles se besef dat gekonsentreerde handeling in drama 'n deug is, vind ook uitdrukking in sy waarskuwing dat die tragediedigter nie van 'n epiese samestelling van stof 'n tragedie moet probeer maak nie, met ander woorde dat hy nie die hele verhaal van die lias in een tragedie moet probeer weergee nie, omdat digters wat dit in die verlede gedoen het, swak gevaar het in dramakompetisies (Aristoteles se aanvoeling dat die fabula verwerk moet word tot sjuzet, kyk voetnoot 9 op p. 30). In 26.62a18-b2 waar Aristoteles die epos en die tragedie teen mekaar opweeg, en aan die tragedie voorkeur gee omdat dit die doel van die uitbeelding binne 'n kleiner omvang verwesenlik, stel hy dit eksplisiet: "... want 'n meer gekonsentreerde handeling is genotvoller as een wat deur ' $n$ lang tydsverloop verdun is ...". Hy het dus reeds die aanvoeling gehad dat groter gekonsentreerdheid 'n deug is, maar hy het nog nie so ver gegaan om te sê hoekom die toeskouer dit meer genotvol sal vind nie.

\subsection{Levitt se teorie van die aanvangspunt as bepalende faktor vir die spanningsvlak}

'n Meer wetenskaplike formulering van basies dieselfde siening is sowat 2400 jaar later deur P.M. Levitt (1971:24-34) gegee. Hy het ook daardie enkele stappie verder as

15 Dit is die siening van Elsc (1957:207-219) wat glo dat Aristoteles na die tyd verwys wat dit neem om 'n tragedie op te voer: 'n persoon moet in staat wees om 'n tragedie "binne een omwenteling van die son" te sien/lecs. Maar dit lyk na 'n oorbeklemtoning van die voor die hand liggende. 
Aristoteles gegaan deur gekonsentreerdheid in verband te bring met dramatiese spanning. Levitt het die rede vir gekonsentreerde of nie-gekonsentreerde handeling gesoek in die aanvangspunt van die handeling in 'n drama, wat hy die point of attack genoem het. Hy onderskei dan tussen dramas met 'n early point-of-attack waarin die hele storie gedramatiseer word en waarin die struktuur diffuus sal wees, en dramas met 'n late pointof-attack waarin slegs 'n deel van die storie gedramatiseer word. In die laasgenoemde geval waar die handeling beperk is tot die laaste paar uur voor die klimaks, sal die strukturele patroon uiteraard baie gekonsentreerd wees en die spanningsvlak dienooreenkomstig hoog.

\section{Identifikasie van die toeskouer met die dramatiese figuur}

\subsection{Graad van identifikasie bepaal intensiteit van spanning}

Een van die belangrikste faktore in die bepaling van die intensiteit van die spanning in 'n drama is die mate waarin die toeskouer homself kan identifiseer met die hooffiguur. Pfister (1988:99-100) het aangetoon dat hoe sterker die identifikasie is, hoe meer betrokke die toeskouer sal wees, en met hoe meer belangstelling hy die planne, alternatiewe moontlikhede en risiko's in die opeenvolgende dramatiese situasies sal volg. Vanuit 'n heel ander hoek het twee kommunikasie-deskundiges, P. Comisky en J. Bryant, ná verskeie wetenskaplike eksperimente op 150 voorgraadse studente, ook tot die konklusie gekom dat 'n sterk positiewe ingesteldheid teenoor 'n figuur in 'n situasie die spanning grootliks verhoog. ${ }^{16}$

Die identifikasieproses vind egter nie vanself of per toeval plaas nie, maar moet deur die dramaturg teweeggebring word deur vernuftige manipulering van die teks. Pfister (1988:99-100) toon dan ook aan dat daar reeds vroeg in die drama baie moeite gedoen is om die toeskouer vroegtydig positief in te stel teenoor die betrokke dramatiese figuur deurdat die situasie waarin die dramatiese figuur hom bevind, sy karakter en motivering op só 'n wyse uitbeeld dat die toeskouer die figuur intiem sal leer ken en hom in sy situasie sal kan indink.

\subsection{Aristoteles se siening van die ideale tragiese held}

Die belangrikheid van die identifisering van die toeskouer met die dramatiese figuur is reeds deur Aristoteles ingesien. Die ideale tragiese held moet, soos alle karakters in Griekse tragedie, goed wees (spoedaios, 2.48a2, en chrêstos, 15.54a17), maar hy moet nie "'n toonbeeld van deugdelikheid en regverdigheid" (13.53a8) wees nie omdat die gewone mens nie met so 'n voortreflike mens sal kan identifiseer nie. Hy moet egter ook nie as gevolg van slegtheid en skurkagtigheid in rampspoed beland nie (13.58a8-9), maar as gevolg van die een of ander hamartia ${ }^{17}$ (13.53a 13-15). Hy moet dus soos ons wees (15.54a24-25), met

16 Comisky en Bryant 1982:49-58. Vgl. ook Griffiths (1982:24): "Suspense requires sympathy with the characters." Mouton (1989:61) verwys na dic kommunikasieproses tussen die toeskouers en die spelers wat in 'n groot mate bepalend is vir die genot en bevrediging wat die toeskouers uit die opvocring kry.

17 Oor die presiese konnotasie wat aan die woord hamania geheg moet word, woed daar al ceue lank 'n polemick. Vanuil Arisloteles se perspektief van die ideale tragiese held, kan die woord nie 
ander woorde naby genoeg aan ons dat ons ons in sy posisie kan indink, maar nie so naby dat ons nie meer respek vir hom het nie. Aristoteles stel dit dan ook dat die tragiese held beter as die norm moet wees (2.48a 17-18); trouens, hy moet uit die geledere kom van diegene "wat groot aansien en voorspoed geniet, soos byvoorbeeld Oidipus en Thuestes" (13.53a10-12). As die held van 'n hoë sosiale stand is, sal die verandering in sy lot meer radikaal wees, en sal sy val dus soveel meer skokkend wees.

Uit die algemene riglyne vir die karakterisering van dramatiese figure wat Aristoteles bied asook uit sy beskrywing van die ideale tragiese held blyk dit dus duidelik dat hy deeglik bewus was van die belangrikheid van die identifisering van die toeskouer met die dramatiese figure.

\section{Die emosies medelye en vrees}

\section{1 'n Resepsie-estetiese insig 2400 jaar gelede}

Die proses van identifisering met die dramatiese figure en die toeskouer se betrokkenheid by die gebeure impliseer dat hy sekere gewaarwordinge sal ervaar by die aanskouing van 'n drama. Om 'n literêre werk vanuit die leser se belewenis daarvan te benader, is vandag die normale werkwyse in die resepsie-estetika, ${ }^{18}$ maar dis werklik 'n verstommende insig om 2400 jaar gelede tot die besef te gekom het dat die toeskouer se identifisering met die figure op die verhoog tot gevoelens van medelye en vrees aanleiding gee, en dan die implikasies van hierdie waarneming vir die finale effek van die drama uit te spel.

\subsection{Die rol van die emosies medelye en vrees in Aristoteles se teorie}

Die belangrike rol wat die emosies medelye en vrees speel in die hele teorie oor drama wat Aristoteles in die Poëtika uiteensit, blyk uit die feit dat albei emosies in die definisie van tragedie vermeld word as kwalifikasies van die tipe handeling wat in tragedie uitgebeeld word: "Tragedie, dan, is die uitbeelding van 'n handeling wat ... deur (die verwekking) van

'n ernstige morele defek in die karakter van die held beteken soos in die Victoriaanse era geglo is nie, aangesien 'n persoon wat sy lot verdien, nie met veel simpatie bejeën sal word nie. Dit is egter ook nie 'n suiwer intellektuelc fout, met ander woorde 'n vergissing of 'n oordeclsfout nie, want dan sal die held te ver verwyderd wees van die gewone mens, terwyl Aristoteles juis wou gehad het dat hy tussen dic uiterstes van goed en sleg moet wees en 'soos ons' moet wees. In resente jare het 'n toencmende aantal gcleerdes dus 'n meer omvattende interpretasie voorgestaan, wat sowel "ignorance of fact" as "some defect of character" insluit (bv. onder andere Gresseth, 1958:315-318; Stinton, 1975:254; Van der Ben, 1976:1-16; Moles, 1979:77-94 en Halliwell, 1986:221-222).

$18 \quad \mathrm{Vgl}$. Selden (1985:125): "We can no longer talk about the meaning of a text without considering the reader's contribution to it." Daar sal nie op die fyner besonderhede van die rescpsictcorieë ingegaan word nie, aangesien slegs die beginsel hier van belang is. Vir meer besonderhede kyk Selden (1985:106-125), asook Holub (1984). Vgl. egter die opmerking van Pavis (1982:70) in verband met drama: "... the question of its (=the theatrical work's) reception by the spectator seems to have been totally neglected, except for the famous instance of catharsis or its Brcchtian counterpoint, alienation ... the modalities of reception and the work of interpreting the performance are very poorly understood". 
medelye en vrees (by die toeskouers) die katarsis van sodanige emosies bewerkstellig" (6.49b24-28). Die korrekte interpretasie van hierdie frase is reeds vir eeue lank 'n probleem. Die waarskynlikste verklaring van die bostaande gedeelte is dat die aanbieding van vrees- en medelywekkende gebeure in 'n tragedie soortgelyke emosies by die toeskouers wek, en dat hierdie emosies wat op homeopatiese wyse gestimuleer is, deur die proses van katarsis weer tot bedaring gebring word ná afloop van die tragedie.

\subsection{Die tipe gebeure wat vrees en medelye wek}

Aristoteles gaan ook in op die tipe gebeure wat vrees en medelye die geredelikste sal wek. In 9.52a1-4 konstateer hy dat gebeure wat teen die verwagting, maar tog ten gevolge van mekaar gebeur, die mees effektiewe is. Ohlander (1985:13-14) verduidelik hierdie opmerking van Aristoteles soos volg: "When we not only are unprepared for an event but hope or expect something else to happen, we are caught off guard ... and suffer all the more with the hero." In 14.53b14-22 spesifiseer Aristoteles die soort gebeure wat mense as verskriklik of deerniswekkend ervaar. Dit is die tragiese dade wat hulle binne die kader van 'n familiekring afspeel, byvoorbeeld "wanneer 'n broer sy suster, of 'n seun sy vader, of 'n moeder haar seun, of 'n seun sy moeder doodmaak of wil doodmaak". Uiteraard sal hierdie soort gebeure ook teen die verwagting gebeur. Die feit dat Aristoteles voornemende dramaturge aanraai om sulke situasies te dramatiseer, laat 'n mens verstaan waarom Plato so sterk te velde getrek het teen die verderflike invloed van tragedie op die toeskouers (Die Staat 3. 386-392)!

\subsection{Die verwekking van die emosies medelye en vrees as die uiteindelike doel van die tragediedigter}

As't ware die kulminasie van die teorie wat opgebou is uit Aristoteles se wydverspreide opmerkings in verband met dramatiese spanning, is sy gedagte dat "die genot wat die tragediedigter moet verskaf sy oorsprong het in medelye en vrees" (14.53b11-13). As 'n mens dit sou lees saam met sy opmerking in 26.62b 12-15 waar die doel of funksie (telos) van tragedie gelykgestel word met die verwekking van die genot eie aan tragedie, is dit nie vergesog om te sê dat die uiteindelike doel van die tragediedigter volgens Aristoteles die verwekking van die emosies medelye en vrees moet wees nie.

Die vraag sou wel gevra kon word hoe sulke pynvolle emosies soos medelye en vrees genot kon verskaf, of in vandag se terme, hoe spanning wat tog nie op sigself 'n positiewe ervaring is nie, aangenaam kan wees. Hierdie probleem kan vanuit twee perspektiewe beskou word. Die eerste is Aristoteles se siening van katarsis. Indien 'n mens sou aanvaar dat die aanbieding van medely- en vreeswekkende gebeure die ooreenstemmende emosies in 'n tragedie wek, en dat hierdie emosies deur die proses van katarsis aan die einde van die tragedie weer tot bedaring gebring word, is dit duidelik dat die opheffing van emosionele spanning ' $n$ aangename ervaring sal wees. Die belewenis van hierdie inherent pynvolle ervaring sal dus uiteindelik 'n gevoel produseer wat bondig 'genot' genoem kan word.

Maar daar is nog 'n antwoord op die bostaande vraag. Horatius het sowat 300 jaar later in sy Ars Poetica (reëls 333 e.v.) gekonstateer dat die dramaturg 'n tweeledige taak het, te 
wete om die gehoor te leer en om hulle te vermaak. Alhoewel Aristoteles dit nie so eksplisiet in die Poëtika stel nie, blyk dit tog dat ook hy van mening was dat die tragediedigter hierdie twee take het. Dat hy na die verwekking van genot streef, het reeds geblyk; dat hy wil leer, blyk uit hoofstuk 4, waar Aristoteles beweer dat ons dit geniet om na akkurate afbeeldings van dinge te kyk waarvan die oorspronklike vir ons pynlik is om te sien (4.48b911). Die verklaring van hierdie skynbaar paradoksale waarneming vind hy daarin dat mense leer en tot konklusies kom wanneer hulle die afbeeldings beskou, en om te leer is aangenaam (4.48b10-17). Die afleiding kan dus gemaak word dat om die intrinsiek pynvolle emosies vrees en medelye te ervaar, uiteindelik aangenaam is, aangesien 'n mens daaruit leer, en 'n nuwe perspektief op die gebeure in die drama kry.

Aristoteles se opmerkings in verband met dramatiese spanning in die Poëtika is so wydverspreid en uiteenlopend van aard dat dit hoogs onwaarskynlik lyk dat hy die bedoeling gehad het dat dit as 'n sistematiese teorie oor dié onderwerp beskou moet word. Tog het dit geblyk dat sy sienings in hierdie verband, alhoewel dit 2400 jaar gelede te boek gestel is, in vele opsigte die basis vir die moderne dramateorie vorm. Die klem wat hy op die liniêre plot en kousale samehang plaas, is 'n vroeë herkenning van twee absolute vereistes vir eenheid in 'n drama. Sy aanvoeling vir die fases in die handelingsverloop wat deur onder andere Scaliger, Freytag en Verhagen nagevolg en verder ontwikkel is, word in breë trekke vandag nog so aanvaar. Die wenslikheid van gekonsentreerde handeling en van die identifikasie van die toeskouer met die dramatiese figuur is faktore wat vandag nog ewe geldig is. So ook is sy bespreking van die effek wat die tragedie op die toeskouers het, die uitgangspunt van die moderne resepsie-estetika.

\section{Aangehaalde werke}

Comisky, P. \& Bryant, J. 1982. Factors Involved in Generating Suspense. Human Communication Reseanch, 9(1):49-58.

Conradie P. 1979. Hoe om ' $n$ drama te ontleed. Blokboek. Pretoria \& Kaapstad : Academica.

Dawson, S.W. 1970. Drama and the Dramatic. London : Methuen \& Co.

Elam, K. 1980. The Semiotics of Theatre and Drama. London : Methuen \& Co.

Else, G.F. 1957. Aristotle's Poetics: The Argument. Cambridge, Mass. : Harvard University Press.

Freytag, G. 1965 (1922). Die Technik des Dramas. Darmstadt : Wissenschaftliche Buchgesellschaft. Goodine, J.F. 1977. The Role of Suspense in Dramatic Comedy. Ann Arbor : UMI.

Gresseth, G.K. 1958. The System of Aristotle's Poetics. Transactions and Proceedings of the American Philological Association, 89:312-335.

Griffiths, S. 1988. How Plays are Made. A Guide to the Technique of Play Construction and the Basic Principles of Drama. London : Heinemann Educational.

Hamilton, C. 1939. The Theory of the Theatre and Other Principles of Dramatic Criticism. New York: Henry Holt \& Co.

Hall, D. 1981. To Read Literature. Fiction. Poetry. Drama. New York : Holt, Reinhart \& Winston.

Halliwell, D. 1986. Aristotle's Poetics. London : Duckworth.

Holub, R.C. 1984. Reception Theory. A Critical Introduction. London \& New York : Methuen \& Co. Kenyon, F.G. 1951. Books and Readers in Ancient Greece and Rome. Oxford : Clarendon Press.

Kock, T. 1884. Comiconum Atticonum Fragmenta. Leipzig: Teubner.

Levitt, P.M. 1971. A Structural Approach to the Analysis of Drama. The Hague : Mouton.

Langer, S.K. 1953. The Dramatic llusion. Feeling and Form. A Theory of An. New York : Scribner's. pp. 306-325.

Lucas, D.W. 1968. Aristotle. Poetics. Oxford : Clarendon Press.

Moles, J. 1979. Notes on Aristotle Poetics 13 and 14. Classical Quarterly, 29:77-94. 
Mouton, M. 1989. Dramateorie vandag: die bydrae van die drama-en teatersemiotiek. Potchefstroom : Departement Scntralc Publikasics, PU vir CHO.

Nicoll, A. 1962. The Theatre and Dramatic Theory. London : Georgc G. Harrap.

Ohlander, S.P. 1985. Dramatic Suspense in Euripides' and Seneca's Medea. Ann Arbor: UMI.

Pavis, P. 1982. Languages of the Stage: Essays in the Semiology of the Theatre. New York : Performing Arts Journal Publications.

Pfister, M. 1988. The Theory and Analysis of Drama. Translated from the German by J. Halliday. Cambridge : Cambridgc University Press.

Pratt, N.T. Jr. 1939. Dramatic Suspense in Seneca and his Greek Precursors. Princeton : Princcton University Press.

Pütz, P. 1970. Die Zeit im Drama. Zur Technik dramatischer Spannung. Göttingen : Vandenhoeck \& Ruprecht.

Selden, R. 1985. A Reader's Guide to Contemporary Literary Theory. Sussex : The Harvester Press Limited.

Stinton, T.C.W. 1975. Hamartia in Aristotle and Greek Tragedy. Classical Quarterly, 25:221-254.

Stuart, D.C. 1918. Foreshadowing in the Euripidean Prolog. Studies in Philology, 15:295-306.

Taplin, O. 1978. Greek Tragedy in Action. Berkeley : University of California.

Thompson, A.R. 1946. The Anatomy of Drama. Berkeley: University of California Press.

Van der Ben, N. 1976. Aristotle Poetics 1449b27-28. In: Brcmer, J.M., Radt, S.L., Ruijgh, C.J. (eds.). Miscellanea Tragica in honorem J.C. Kamerbeek. Amsterdam : Hakkert. p. 1-16.

Van Gorp, H. c.a. 1986. Lexicon van literaire tennen. Groningen : Woltcrs-Noordhoff.

Verhagen, B. 1963 (1927). Dramaturgie. Amsterdam : Moussault Uitgeverij.

\section{Universiteit van die Oranje-Vrystaat}


